\title{
Morphological and molecular analyses in Scleroderma (Basidiomycota) associated with exotic forests in Pampa biome, southern Brazil
}

\author{
Montagner DF ${ }^{1}$, Coelho G ${ }^{2}$, Silveira $\mathrm{AO}^{3}$, Baldoni $\mathrm{DB}^{4}$ and Antoniolli $\mathrm{ZI}^{4}$ \\ ${ }^{1}$ Universidade Federal de Santa Maria. Programa Pós-graduação Agrobiologia. Av. Roraima $n^{o} 1000$ - Campus - \\ Bairro Camobi - CEP: 97105-900, Santa Maria - Rio Grande do Sul, Brazil \\ ${ }^{2}$ Departamento de Fundamentos da Educação, Universidade Federal de Santa Maria, RS, Brazil \\ ${ }^{3}$ Departamento de Engenharia Sanitária e Ambiental, Universidade Federal de Santa Maria, RS, Brazil \\ ${ }^{4}$ Departamento de Solos, Universidade Federal de Santa Maria, RS, Brazil.
}

Montagner DF, Coelho G, Silveira AO, Baldoni DB and Antoniolli ZI 2015 - Morphological and molecular analyses in Scleroderma (Basidiomycota) associated with exotic forests in Pampa biome, southern Brazil. Mycosphere 6(3), 337-344, Doi 10.5943/mycosphere/6/3/9

\begin{abstract}
Basidiomes of the mycorrhizal genus Scleroderma were collected on exotic forest soils (associated with Eucalyptus and Pinus) from Pampa biome, southern part of Rio Grande do Sul State, Brazil. Three species were identified, using both morphological and molecular approaches as follows: S. albidum, $S$. citrinum, and $S$. verrucosum. New ITS rDNA sequences generated in this study, together with others retrieved from GenBank, showed the species nesting in two main clades headed by $S$. albidum and S. citrinum. Morphological descriptions are provided for these two species. Infrageneric dichotomy represents a separation into combinations of reticulate spores plus clamped hyphae and echinulate spores plus simple-septate hyphae.
\end{abstract}

Key words - gasteroid fungi - phylogenetic analysis - soil symbionts

\section{Introduction}

The Pampa bioma is one of six Brazilian biomes, being restricted to the southern part of Rio Grande do Sul State, Brazil. It comprises $176,469 \mathrm{~km}^{2}$ in area, $64 \%$ of the States territory and $2.07 \%$ of Brazilian territory. This biome shares physiognomic characters with Pampean region of Uruguay and Northern Argentina (Boldrini et al. 2010, IBGE 2013). The predominant vegetation of this biome includes grasses, shrubs and riparian forests. Recent data point to nearly 3000 plant species, some being endemic to Pampean region (Boldrini et al. 2010, Iganci et al. 2011).

Large areas are cultivated with exotic forest species, mainly Eucalyptus spp. and Pinus spp. little is known of the ectomycorrhizal diversity associated with these exotic forests. Recently specimens of the genus Scleroderma Pers. were found as a mycorrhizal component within the Pampa biome. Scleroderma is found in tropical, temperate and subtropical ecosystems worldwide. About 25 species are recognized morphologically, with 12 being reported from Brazil (Guzmán 1970, Sims et al. 1995, Baseia \& Milanez 2000, Giachini et al. 2000, Sobestiansky 2005, Meijer 2006, Gurgel et al. 2008, Sanon et al. 2009, Cortez et al. 2011). The diagnostic characters for the genus are gasteroid basidiome of epigeous habit, rarely hypogeous, and globose to subglobose 
basidiospores with ornamentation reticulate to echinulate (Guzmán 1970, Giachini et al. 2000, Cortez et al. 2011, Yousaf et al. 2012, Nouhra et al. 2012).

Knowledge about the genus Scleroderma in Pampa biome is limited, the main work is of Cortez et al. 2011, who identified seven species: S. albidum Pat. \& Trab. emend. Guzmán, S. bovista Fr., S. citrinum Pers., S. dictyosporum Pat., S. fuscum (Corda) E. Fisch., S. leave Lloyd emend. Guzmán, and S. verrucosum (Bull.) Pers. However, a molecular approach to studying Scleroderma in Brazil is lacking, although it has been used elsewhere on a restricted number of species and specimens (Phosri et al. 2009, Sanon et al. 2009, Nouhra et al. 2012, Kumla et al. 2013, Zhang et al. 2013, Rusevska et al. 2014).

The purpose of this work is to contribute to the identification of Scleroderma species from Pampa Biome through morphological and molecular analysis in order to improve mycorrhizal fungi studies. It will also contribute to phylogenetic studies in Scleroderma, still incipient in worldwide scientific literature, with new molecular data available in public databases.

\section{Materials \& Methods}

\section{Isolates and morphology}

Collection of species - Fresh basidiomes were obtained during mycological trips in the region of Pampa biome in Rio Grande do Sul State, Brazil. The basidiomes were collected in the top soil, near to Eucalyptus spp. and Pinus spp. trees. They were collected from September 2010 to October 2013 in municipalities of Barra do Quaraí, Bororé, Jaguarí, Pinhal Grande, Santa Maria, Santana do Livramento and São Francisco de Assis.

Identification and morphological description - Fresh basidiomata were collected and analyzed macro- and microscopically following Brundrett et al. (1996). Basidiomes were photographed in situ and their colour names were compared and noted according to Munsell Soil Color Charts (2009). Microscopical characters were analyzed in optical microscope (Olympus CX40), from handmade sections with razor blades, and rehydrated in $3 \% \mathrm{KOH}(\mathrm{v} / \mathrm{v})$. At least 35 measurements of each microstructure were obtained, usually including ornamentation of the spores (or not for comparison with literature). For scanning electronic microscopy (SEM) of spores, herbarium specimens were mounted directly on aluminum stubs with a carbon band and subsequently covered with a layer of gold with $15 \mathrm{~nm}$ in thickness, using a Balzers SCD 050 Sputter. Spores were examined in microscope model JEOL - JSM 6060. Basidiomes were dried in Marconi dryer model MA033 at $45-50^{\circ} \mathrm{C}$. Specimens were deposited at SMDB herbarium (Department of Biology, Federal University of Santa Maria).

\section{Molecular analysis}

For DNA sample, a fraction of the fresh basidiome was removed for storage in CTAB (Gardes \& Bruns 1993) at $-20^{\circ} \mathrm{C}$ until the time of analysis. DNA was extracted with the DNeasy® Plant Mini Kit (Qiagen, São Paulo, Brazil) kit. For the extraction of DNA from herbarium specimens, EZNA® Forensic DNA Extraction Kit (Omega Bio-tek, product No. D3591-01) was used. The complete region in nrDNA (ITS1-5.8S-ITS2) was amplified with primers ITS1 and ITS4 (White et al. 1990). The amplification reaction of the rDNA fragments was performed according Baldoni et al. (2012). After the PCR amplification, electrophoresis was performed in $1.5 \%$ agarose gel and $1 \mathrm{X}$ TBE buffer. The DNA samples were stained with BlueGreen Loading Dye I ${ }^{\circledR}$ (LGC Biotechnology, Cotia, Brazil) and observed under UV light. The PCR products were purified with Gen Elute PCR Clean-up Kit® (Sigma, St. Louis, USA) kit, following the manufacturer's instructions.

Sequencing of the samples was performed into the sequencer, ABI PRISM 3100 Genetic Analyzer (Applied Biosystems). Sequenced fragments were analyzed using the Staden Package 2.0.0b program (Staden et al. 2003) for obtaining consensus sequences, and then deposited in GenBank. The sequences were aligned in Bioedit program. The phylogenetic relationship of the specimens was reconstructed based on analyses of the ITS region in MEGA 5.0 software (Tamura 
et al. 2011), with the analysis of Maximum Likelihood (ML) in a total of 1000 replications for all reconstructions. The model of nucleotide substitution General Time Reversible model was estimated using JModelTest as the best model to solve the data (Posada et al. 2006), performed with uniform rates and parameters for partial exemption (95\%). Selected closely related sequences for phylogenetic analysis of the genus Scleroderma were retrieved from the GenBank database (http://www.ncbi.nlm.nih.gov/genbank/). Forty-four sequences (Table 1) including the outgroup taxa Pisolithus tinctorius (AF374632) and Pisolithus albus (AF440868) were used for analyses.

Table 1 - List of species included in phylogenetic analysis, herbarium number, place of origin, and GenBank accession numbers.

\begin{tabular}{|c|c|c|c|}
\hline Species & Strain /Specimen & Origin & GenBank \\
\hline Scleroderma albidum & ICN 154608 & Santa Maria, Brazil & KJ676532 \\
\hline Scleroderma albidum & SMDB 14.507 & Barra do Quaraí, Brazil & KJ676521 \\
\hline Scleroderma albidum & SMDB 14.503 & Bororé, Brazil & KJ676522 \\
\hline Scleroderma albidum & SMDB 14.517 & Bororé, Brazil & KJ676523 \\
\hline Scleroderma albidum & SMDB 14.516 & Jaguarí, Brazil & KJ676524 \\
\hline Scleroderma albidum & SMDB 14.508 & Jaguarí, Brazil & KJ676525 \\
\hline Scleroderma albidum & SMDB 14.512 & Santa Maria, Brazil & KJ676526 \\
\hline Scleroderma albidum & SMDB 14.513 & Pinhal Grande, Brazil & KJ676527 \\
\hline Scleroderma albidum & SMDB 14.510 & Sant. do Livramento, Brazil & KJ676528 \\
\hline Scleroderma albidum & SMDB 14.509 & Sant. do Livramento, Brazil & KJ676529 \\
\hline Scleroderma albidum & SMDB 14.511 & Sant. do Livramento, Brazil & KJ676530 \\
\hline Scleroderma albidum & SMDB 14.514 & São Franc. de Assis, Brazil & KJ676531 \\
\hline Scleroderma areolatum & PBM2205 & USA & EU718116 \\
\hline Scleroderma areolatum & JMP00080 & USA & EU819438 \\
\hline Scleroderma areolatum & RBG/Kew K(M)125392 & England & EU784407 \\
\hline Scleroderma areolatum & E00278286 & Dane County, WI, USA & FM213353 \\
\hline Scleroderma areolatum & F:PGK193 & USA & GQ166910 \\
\hline Scleroderma aurantium & $8-5$ & Sichuan, China & HM237174 \\
\hline Scleroderma bovista & $\mathrm{K}(\mathrm{M}) 105588$ & England & EU784409 \\
\hline Scleroderma bovista & RT00034 & USA & EU819517 \\
\hline Scleroderma bovista & BCN-MPM1989 & Catalonia, Spain & FM213340 \\
\hline Scleroderma bovista & $5-1$ & Sichuan, China & HM237175 \\
\hline Scleroderma bovista & O1A_1 & USA & JX030276 \\
\hline Scleroderma bovista & O1Q_1 & USA & JX030277 \\
\hline Scleroderma bovista & Scl_1-1-2LC & USA & JX030217 \\
\hline Scleroderma bovista & Scl_1-2-2LC2 & USA & JX030218 \\
\hline Scleroderma bovista & - & Japan & AB099901 \\
\hline Scleroderma bovista & K80S09 & New Zealand & GQ267487 \\
\hline Scleroderma bovista & CM9 & Pakistan & KF881875 \\
\hline Scleroderma citrinum & Scl_1-3-1H & USA & JX030202 \\
\hline Scleroderma citrinum & Scl_2-2-1H & USA & JX030205 \\
\hline Scleroderma citrinum & Scl_2-2-1HC & USA & JX030207 \\
\hline Scleroderma citrinum & $\mathrm{CH} 1-127$ & USA & JX079368 \\
\hline Scleroderma citrinum & (DNA 778) & Germany & HM189957 \\
\hline Scleroderma citrinum & JMP0082 & USA & EU819440 \\
\hline Scleroderma citrinum & SMDB: 14.500 & Santa Maria, Brazil & KJ679575 \\
\hline Scleroderma citrinum & SMDB: 14.499 & Santa Maria, Brazil & KJ679576 \\
\hline Scleroderma verrucosum & ICN: 154625 & Santa Maria, Brazil & KJ676520 \\
\hline Scleroderma verrucosum & 06MCF7265_E10/45-09 & Macedonia & HF933241 \\
\hline Scleroderma verrucosum & $\mathrm{K}(\mathrm{M}) 30670$ & - & EU784415 \\
\hline Scleroderma verrucosum & 07MCF7984_E10/45-11 & Macedonia & HF933232 \\
\hline Scleroderma sp. & P091 & Estônia & FN669245 \\
\hline Scleroderma sp. & $5-2$ & China, Sichuan & HM237172 \\
\hline Scleroderma sp. & ScT-X-08 & "Montenegro: Tivat" & JQ685726 \\
\hline Pisolithus albus & $\mathrm{T} 25070$ & Australia & AF440868 \\
\hline Pisolithus tinctorius & MARX270 & Georgia, USA & AF374632 \\
\hline
\end{tabular}

Bold Scleroderma species obtained from Pampa biome / RS 


\section{Results}

\section{Taxonomy descriptions}

Scleroderma albidum Pat. \& Trab. emend. Guzmán, Darwiniana 16: 295 (1970)

Figs. 1-2

Basidiomata epigeous, 6-39 mm high, 6.7-37 mm in diam., globose to subglobose; surface smooth, cracked, to squamulous, background yellow (8/6-7/6 2.5Y) to brownish yellow (6/6 0YR), cracks small $( \pm 0.5 \mathrm{~mm})$, irregular, olive yellow $(6 / 82.5 \mathrm{Y})$ at the top; squamules small, very pale brown (8/3-8/4 10YR) light olive brown (5/6 2.5Y), dark yellow brown (4/4 10YR), yellow $(8 / 8-7 / 82.5 \mathrm{Y})$ in the base. Rhizomorphs more aggregated at the base, pale brown $(8 / 42.5 \mathrm{Y})$, branched, narrowing towards the end, $0.3 \mathrm{~mm}$ in diam. Peridium $0.5-1.65 \mathrm{~mm}$ when fresh, rubbery in consistence, very pale brown (8/4 10YR). Gleba compact when young, becoming pulverulent at maturity, light brownish gray (6/2 10YR), grayish black (2.5 10YR), reddish brown (4/3 10YR) to dark brown (3/2 10YR).

Basidiospores globose, echinulate, dark brown in $\mathrm{KOH}, 8-17 \times 9-17 \mu \mathrm{m}$ in diam., including ornamentation, $\mathrm{n}=120 / 2$, coated by crowded curved spines. Basidia not observed. Peridium consisting of two distinct layers. Exoperidium a layer formed by hyphae simple-septate, with slightly thickened walls (ca. $1 \mu \mathrm{m}$ ), interwoven, often ramified and superimposed, hyaline to yellowish brown, 1.5-8.5 $\mu \mathrm{m}$ in diam. $\mathrm{n}=120 / 2$. Endoperidium consisting of hyphae pseudoparenquimatous, hyaline, thick-walled (ca. $1 \mu \mathrm{m}$ ), rounded at the end, 2-21 $\mu \mathrm{m}$ in diam. $\mathrm{n}=120 / 2$. Trama 1.5-9 $\mu \mathrm{m}$ in diam., hyphae hyaline, thin-walled (ca. $1 \mu \mathrm{m}$ ), branched, simpleseptate, clamp connections not observed. Conductive hyphae present, somewhat irregular in profile, filled with an amorphous yellowish brown content, up to 3-16 $\mu \mathrm{m}$ in diam. Clamp connections absent.

Material examined - Brazil, Rio Grande do Sul State, Bororé, 24.VIII.2011, leg. M.A. Sulzbacher, A. Silveira \& R.B. Steffen (SMDB 14.503; 14.505; 14.517); Barra do Quaraí, 23.VIII.2011, leg. M.A. Sulzbacher, A. Silveira \& R.B. Steffen (SMDB 14.507); Jaguarí, Serro do Chapadão, 19.I.2011, leg. D.P. Golle, M.A. Sulzbacher \& R.B. Steffen (SMDB 14. 508); 23.X.2010, leg. D.P. Golle, M.A. Sulzbacher, D.B. Baldoni \& M. Lupatini (SMDB 14.516); Pinhal Grande, 31.III.2013, leg. D.F. Montagner (SMDB 14.513); Santana do Livramento, 5.IV.2013, leg. D.F. Montagner, A. Silveira, G. Coelho \& D.B. Baldoni (SMDB 14.509; 14.510; 14.511); Santa Maria, 18.III.2013, leg. D.F. Montagner \& A. Moro (SMDB 14.512); São Francisco de Assis, 23.V.2013, leg. D.F. Montagner \& L. Morandini (SMDB 14.514).

Discussion - Basidiome morphological features of $S$. albidum are somewhat variable, mainly in peridium thickness and spore size, likely reflecting the lack of knowledge on onthogenic basidiome development. Some specimens present spore size and ornamentation, thin peridium, and small squamulae similar those of $S$. verrucosum. It also resembles $S$. cepa by the spore size, peridium hyphal structure and thickness (Guzmán 1970). S. albidum is also macroscopically similar to $S$. bovista, but the former presents a thin peridium and echinulate basidiospores (Nouhra et al. 2012).

Known distribution - Common in Southern Hemisphere, Asia, North America, and Europe (Guzmán 1970, Sulzbacher et al. 2013). Brazil: including the states of Pernambuco (Gurgel et al. 2008); Minas Gerais, Rio de Janeiro, and São Paulo (Guzmán 1970); Santa Catarina (Giachini et al. 2000); and Rio Grande do Sul (Cortez et al. 2011). Associated with Eucalyptus spp.; probably ectomycorrhizal in Eucalyptus plantations.

Basidiomata epigeous, 17.4-38 $\mathrm{mm}$ high, 25-67 $\mathrm{mm}$ in diam.; smooth depressed on top, globose to subglobose, yellowish brown (5/4 10YR) to light yellowish brown (6/4 10YR) when young, and to pale brown (8/4 10YR), yellow (7/8-8/8 5YR) and brownish yellow (6/6-6/8 10YR) at maturity. Surface smooth when young, cracked at the sides and top when mature, cracks yellow 
(5/6 10YR) to dark yellowish brown (4/4 10YR), covered by scales irregular in shape $( \pm 1 \mathrm{~mm})$ yellowish brown (5/8 10YR) concolorous to the cracks to brownish yellow (6/6 10YR). Rhizomorphs numerous, small, $0.20-0.50 \mathrm{~mm}$, concolorous aggregated the base, white $(8 / 22.5 \mathrm{Y})$ to pale yellow (8/4 10YR). Peridium $4 \mathrm{~mm}$ thick, rubbery when fresh, very pale yellow $(9 / 22.5 \mathrm{Y})$, bruising reddish yellow (7/6-6/6 7.5YR), dehiscence irregular, occurring by rupture of the apical portion. Gleba compact when young, white (8/1 5YR) to black (2.5/1 5YR), becoming powdery at maturity, olive brown (4/4 2.5Y) to olive yellow (6/8 5Y).

Basidiospores globose reticulate, yellowish brown in $\mathrm{KOH}, 9-12 \times 14-16 \mu \mathrm{m}$ in diam., $\mathrm{n}=120 / 2$, including ornamentation; Basidia not observed; Peridium consisting of three layers. Exoperidium formed by hyphae interwoven, thin-walled (ca. $1 \mu \mathrm{m}$ ), hyaline, brownish yellow to rust brown in $\mathrm{KOH}$, thick, 4-12 $\mu \mathrm{m}$ in diam. $\mathrm{n}=120 / 2$. Mesoperidium formed by hyphae interwoven, septate, of hyaline hyphae, narrower than those of exoperidium, 2-8 $\mu \mathrm{m}$ in diam. $\mathrm{n}=120 / 2$, slightly thickened walls (ca. $2 \mu \mathrm{m}$ ). Endoperidium formed by hyphae fibulate $2-4 \mu \mathrm{m}$ in diam., thin-walled, hyaline. Clamp connections present.

Material examined - Brazil, Rio Grande do Sul State, Santa Maria, 28.III.2013, leg. D.F. Montagner (SMDB 14.499; 14.500; 14.501; 14.502).

Discussion $-S$. citrinum is the easiest recognized species in the area, usually being found in Pinus Plantations. It grows somewhat variable in size, but usually is found as bigger basidiomes with an appearance of orange fruits on soil. They are characterized by thicker squamulose peridium with more vivid brownish colours, dehiscence irregular, and distinctly reticulate basidiospores (Nouhra et al. 2012).

Known distribution - North America, Central Europe, Asia, Africa, South America (Guzmán 1970, Sulzbacher et al. 2013). Brazil: States of Paraíba (Gurgel et al. 2008); São Paulo (Bononi et al. 1981); Paraná (Meijer 2006); Santa Catarina (Giachini et al. 2000); and Rio Grande do Sul (Sobestiansky 2005, Cortez et al. 2011). Associated with Pinus elliottii Engelm. and P. taeda L. plantations; ectomycorrhizal.
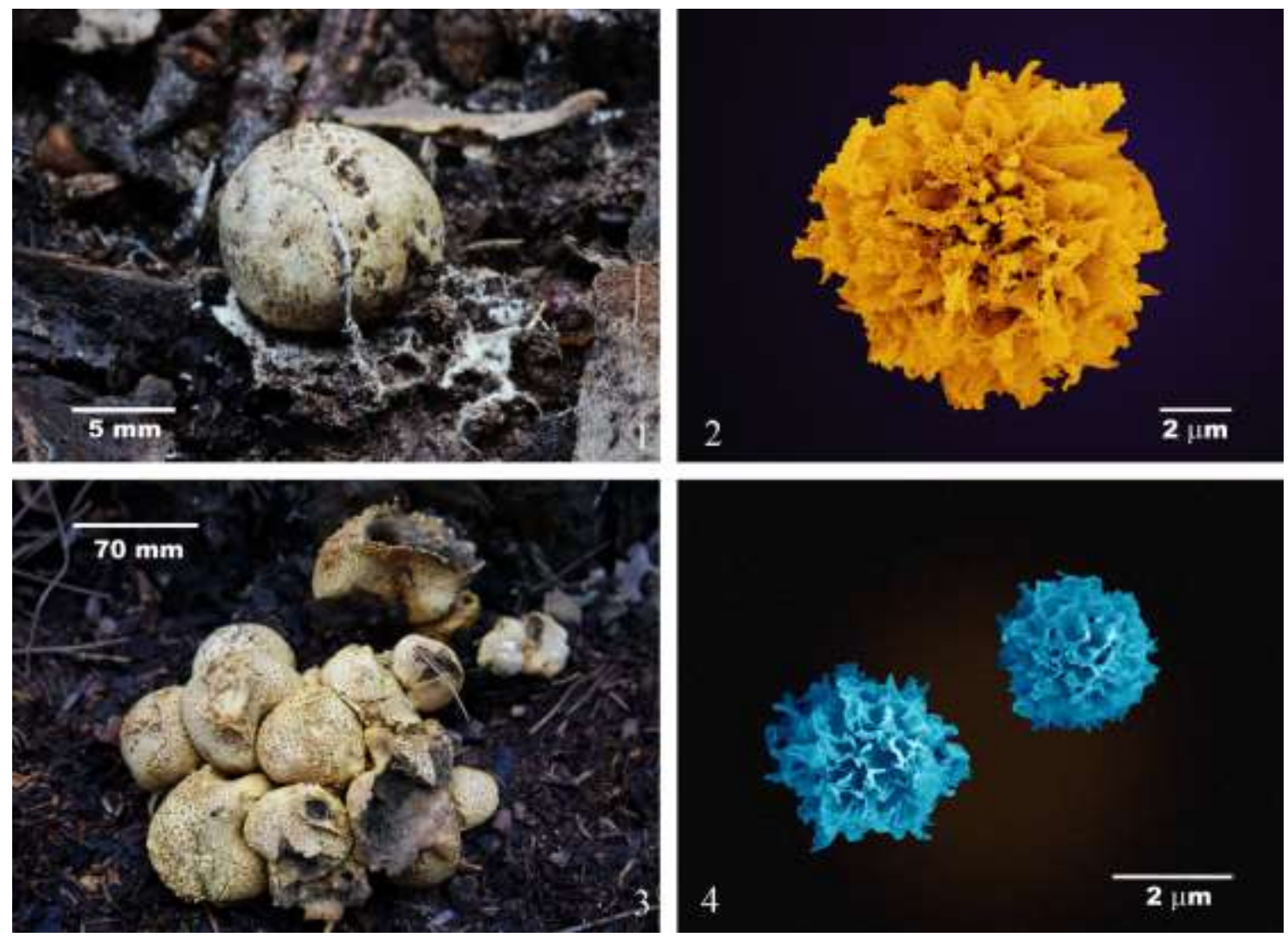

Fig. 1 - Basidiomes and spores of Scleroderma species (SEM). 1-2 S. albidum. 3-4 S. citrinum. 


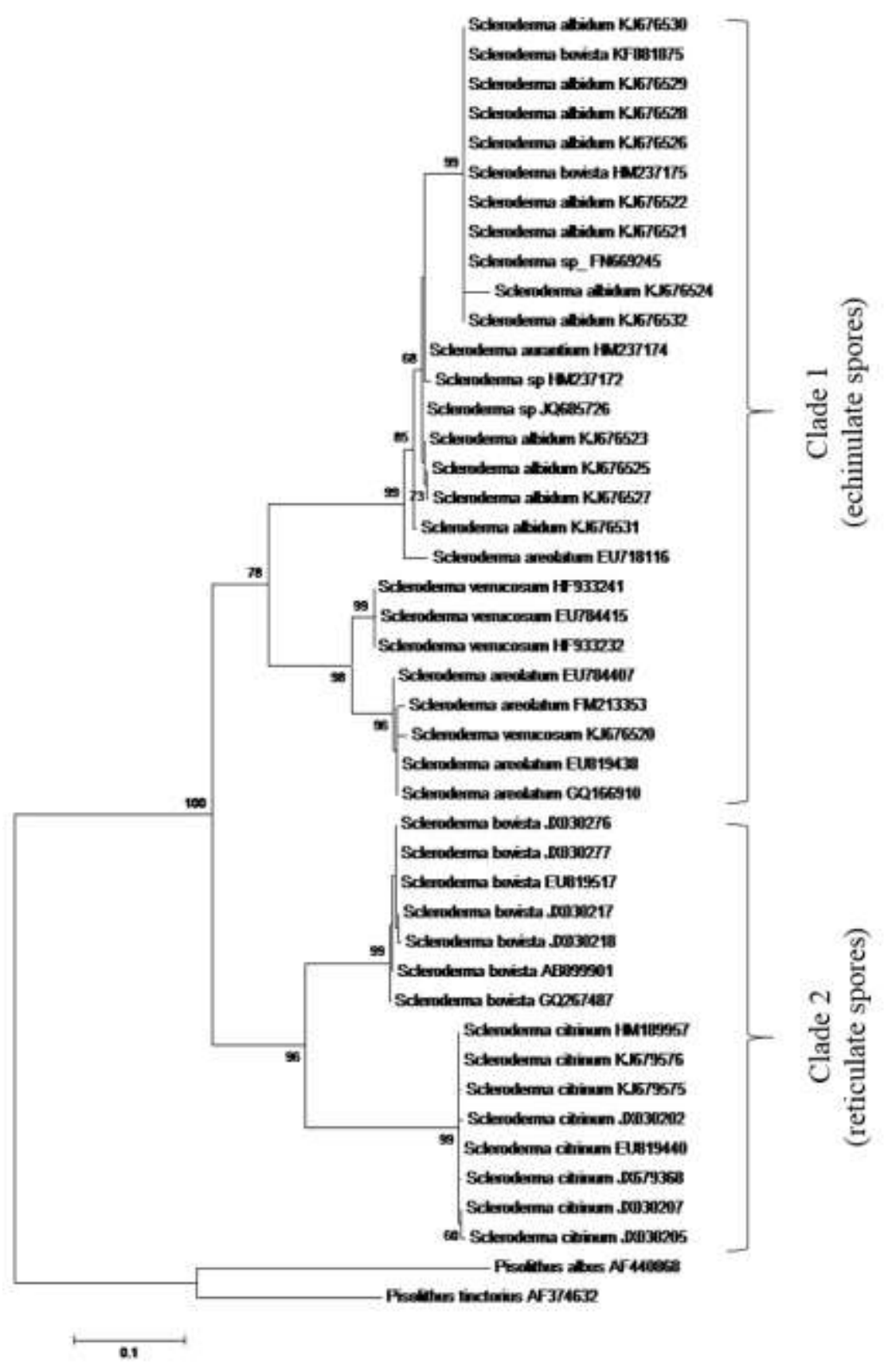

Fig. 2 - Phylogenetic reconstruction of the genus Scleroderma, obtained from ITS1-5.8S-ITS2 sequences. Bootstrap values (in \%) are from maximum likelihood (ML) analyses (1000 bootstraps). The 15 Scleroderma new sequences generated in this study are labeled with the isolation DNA code in Table 1. Sequences from Pisolithus tinctorius and P. albus were used as outgroup.

\section{Phylogenetic analyses}

After sequencing, 15 fragments were obtained from $610 \mathrm{bp}$ to $831 \mathrm{bp}$ of nrDNA ITS region. Phylogenetic analysis based on ITS sequences supported the genus segregation into two major clades; clade 1 for species with echinulate-subreticulate spores plus simple-septate hyphae and clade 2 for species with reticulate spores plus clamped hyphae. This data supports that obtained by other authors (Phosri et al. 2009, Sanon et al. 2009, Nouhra et al. 2012, Kumla et al. 2013, Zhang et al. 2013, Rusevska et al. 2014). An infrageneric separation was initially proposed by Guzmán (1970), but instead, splitting Scleroderma in three sections based on basidiospore ornamentation, as follows: Section Scleroderma for reticulate spores; Aculeatispora for spiny spores; and additionally Sclerangium for subreticulate spores. 
As shown in topology of Scleroderma phylogenetics tree (Fig. 2), Clade 1 included only species with echinulate to subreticulate spores, such as $S$. albidum, $S$. verrucosum, and $S$. areolatum. Most sequences (13 among 15) generated for this study nested together in a conspecific group we called $S$. albidum clade. This fact is remarkable, because they seemed to represent a group of different species by preliminary morphology observation, showing some variation in basidiome appearance, spore ornamentation and spore size. All specimens were shown to be genetically closely related, without dependence on their diverse collection localities. In this clade $S$. albidum, sequences named as Scleroderma bovista (KF881875; HM237175) and S. aurantium (HM237174), two taxa known by their reticulate spores and clamped hyphae (Coker \& Couch 1928), must represent erroneous identifications by presenting highest similarity with other $S$. albidum sequences - obtained from specimens with echinulate spores and simple-septate hyphae. Sequences of Scleroderma sp. (FN669245; JQ685728) from Estonia and Montenegro also claded along with $S$. albidum specimens and are herein conceived as conspecific. The collection of Scleroderma verrucosum ICN 154625 clustering in S. areolatum clade may represent a misidentification.

Clade 2 (Fig.2) nested only species with reticulate spores plus fibulate hyphae coinciding with sect. Scleroderma sensu Guzmán (1970); it formed two groups (S. bovista and S. citrinum). A pair of Brazilian sequences (KJ679576; KJ679575) formed a well supported S. citrinum clade (BT value $96 \%$ ) and high BLAST similarity (98\%) with other sequences from China, USA and Germany.

A restricted set of morphological characters and their states have been a recognized problem in Scleroderma taxonomy providing insufficient data for discriminating species. Another question comes from variable basidiome structure, which can be influenced by soil and environment conditions (Kazuya et al. 2008). Molecular data on the genus must be increasingly generated and used for establishing the limits and phylogenetic relationships of the species (Sanon et al. 2009).

\section{Acknowledgements}

The authors wish to acknowledge the National Council for Scientific and Technological Development (CNPq - Brazil) and the Coordination for the Improvement of Higher Education Personnel (CAPES - Brazil by the grants process 23038.006867/2010-27).

\section{References}

Baldoni DB, Coelho G, Jacques RJS, Silveira RMB, Grebenc T, Antoniolli ZI. 2012 - Brown rotting fungus closely related to Pseudomerulius curtisii (Boletales) recorded for the first time in South America. Mycosphere 3, 533-541.

Baseia IG, Milanez AI. 2000 - First record of Scleroderma polyrhizum Pers. (Gasteromycetes) from Brazil. Acta Botanica Brasilica 14, 181-184.

Boldrini IL, Ferreira PMA, Andrade BO, Schneider AA, Setubal RB, Trevisan R, Freitas EM. 2010 - Bioma Pampa: diversidade florística e fisionômica. Editora Pallotti, Porto Alegre 1, 12-13.

Bononi VLR, Trufem SFB, Grandi RAP. 1981 - Fungos macroscópicos do Parque Estadual das fontes do Ipiranga depositados no Herbário do instituto de Botânica. Rickia 9, 37-53.

Brundrett M, Bougher N, Dell B, Grove T, Malajczuk N. 1996 - Working with mycorrhizas in forestry and agriculture. Canberra, ACIAR, Monograph 32, 373.

Coker WC, Couch JN. 1928 - The Gasteromycetes of Eastern United States and Canada. Chapel Hill 1, 201.

Cortez VG, Baseia IG, Silveira RMB. 2011 - Gasteroid Mycobiota of Rio Grande do Sul, Brazil: Boletales. Journal of Yeast and Fungal Research 2, 44-52.

Gardes M, Bruns TD. 1993 - ITS primers with enhanced specificity for basidiomycetes-application to the identification of mycorrhizae and rusts. Molecular Ecology 2, 113-118.

Giachini AJ, Oliveira VL, Castellano MA, Trappe JM. 2000 - Ectomycorrhizal fungi in Eucalyptus and Pinus plantations in southern Brazil. Mycologia 92, 1166-1177. 
Gurgel FE, Silva BDB, Baseia IG. 2008 - New records of Scleroderma from Northeastern Brazil. Mycotaxon 105, 399-405.

Guzmán G. 1970 - Monografia del género Scleroderma Pers. emend. Fr. (Fungi-Basidiomycetes). Darwiniana 16, 233-407.

Ibge 2013 - Instituto brasileiro de geografia e estatística. Mapa dos biomas brasileiros. http://www.ibge.gov.br/home/presidencia/noticias/21052004biomas.shtm (accessed on 12 November 2013).

Iganci JRV, Heiden G, Miotto STS, Pennington RT. 2011 - Campos de cima da serra: the Brazilian subtropical highland grasslands show an unexpected level of plant endemism. Botanical Journal of the Linnean Society 167, 378-393.

Kasuya MCM, Coelho ID, Tamai Y, Miyamoto T, Yajima T. 2008 - Morphological and molecular characterization of Pisolithus occurring in Hokkaido Island, Northern Japan. Mycoscience 49, 334-338.

Kumla J, Suwannarach N, Bussaban B, Lumyong S. 2013 - Scleroderma suthepense, a new ectomycorrhizal fungus from Thailand. Mycotaxon 123, 1-7.

Meijer AAR. 2006 - Preliminary list of the Macromycetes from the Brazilian State of Paraná. Boletim do Museu Botânico Municipal, Curitiba 68, 01-58.

Munsell Soil Color Charts 2009 - Macbeth Division of Kollinorgen Instruments Corporation.

Nouhra ER, Caffot MLH, Pastor N, Crespo EM. 2012 - The species of Scleroderma from Argentina, including a new species from the Nothofagus forest. Mycologia 104, 488-495.

Phosri C, Martín MP, Watling R, Jeppson M, Sihanonth P. 2009 - Molecular phylogeny and reassessment of some Scleroderma spp. (Gasteromycetes). Anales del Jardín Botánico de Madrid 166, 83-91.

Posada D. 2006 - ModelTest Server: a web-based tool for the statistical selection of models of nucleotide substitution online. Nucleic Acids Research 34, W700-W703.

Rusevska K, Karadelev M, Phosri C, Dueñas M, Watling R, Martín MP. 2014 - Rechecking of the genus Scleroderma (Gasteromycetes) from Macedonia using barcoding approach. Turkish Journal of Botany 38, 375-385.

Sanon KB, Bâ AM, Delaruelale C, Duponnois R, Martin F. 2009 - Morphological and molecular analyses in Scleroderma species associated with some caesalpinioid legumes, Dipterocarpaceae and Phyllanthaceae trees in southern Burkina Faso. Mycorrhiza 19, 571584.

Sims KP, Waltling R, Jeffries P. 1995 - A revised key to the genus Scleroderma. Mycotaxon 56, 403-420.

Sobestiansky G. 2005 - Contribution to a macromycete survey of the States of Rio Grande do Sul and Santa Catarina in Brazil. Brazilian Archives of Biology and Technology 48, 437-457.

Staden R, Judge DP, Bonfield JK. 2003 - Analyzing sequences using the staden package and Emboss. In: Krawetz SA, Womble DD (eds.): Introduction to bioinformatics: a theoretical and practical approach, pp. 393-410. Human Press, Totawa.

Sulzbacher MA, Grebenc T, Jacques RJS, Antoniolli ZI 2013 - Ectomycorrhizal fungi from southern Brazil - a literature-based review, their origin and potential hosts. Mycosphere 4(1), $61-95$.

Tamura K, Kumar S, Nei M. 2011 - Mega: integrated software for molecular evolutionary genetics analysis and sequence alignment. Briefings in Bioinformatics, Baltimore 5, 150-163.

White TJ, Bruns T, Lee S, Taylor J. 1990 - Amplification and direct sequencing of fungal ribosomal RNA genes for phylogenetics. In: Innis MA, Gelfand DH (eds.): PCR protocols: a guide to methods and applications, pp. 315-322. Academic Press, San Diego.

Yousaf N, Khald AN, Niazi AR. 2012 - New records of Scleroderma species (Sclerodermataceae, Agaricomycetes) from Pakistan. Mycotaxon 122, 43-50.

Zhang C, Xu X, Liu J, He M, Wang W, Wang Y, Ji K. 2013 - Scleroderma yunnanense, a new species from South China. Mycotaxon 125, 193-200. 